\title{
Verifikasi Laporan Keuangan: \\ Akses Pendanaan dan Risiko Pada Usaha Kecil dan Menengah
}

\author{
Intan Restu Nurpramitha dan Ronny Prabowo \\ Fakultas Ekonomika dan Bisnis Universitas Kristen Satya Wacana (UKSW) Salatiga \\ Jl. Diponegoro No. 52-60 Sidorejo, Salatiga, 50711, Indonesia
}

\section{Info Article}

Keywords:

Access to Finance; Financial

Statement Verification; SMEs.

ISSN (print) : 2598-7763

ISSN (online): 2598-7771

$\triangle$ Corresponding Author:

Intan Restu Nurpramitha:

Tel. /Fax. 085876877955

E-mail: nurpramitha@gmail.com.

\begin{abstract}
Abtract
This study aims to analyze the effect of financial statement verification on small and medium enterprises' (SMEs) access to finance. Total of all the initial samples was 144 SMEs. After eliminating the criteria, the final sample remaining to be used in this study was 1024 SMEs. This study is a quantitative, using data from The World Bank Indonesia Enterprise Survey 2009 with the ordinal regression test. The results show that financial statement verification positively affects SMEs' access to finance. Thus, this study suggests the importance of financial statement verification for $S M E s$, especially to enhance their financing access as one of SME's main problems.
\end{abstract}

Citation: Nurpramitha, Restu Intan, dan Prabowo, Ronny, (2019). Verifikasi Laporan Keuangan: Akses Pendanaan dan Risiko Pada Usaha Kecil dan Menengah. AFRE Accounting and Financial Review, 2 (1)

\begin{abstract}
Abstraks menjadi masalah utama UKM.

JEL Classification:

DOI: https://doi.org/10.26905/afr.v2i1.3009
\end{abstract}

Penelitian ini bertujuan untuk menganalisis peran verifikasi laporan keuangan dalam meningkatkan akses pendanaan pada UKM. Total dari keseluruhan sampel awal sebanyak 1444 UKM. Kemudian setelah menghilangkan kriteria yaitu jumlah tenaga kerja, sampel akhir yang tersisa untuk digunakan dalam penelitian ini sebanyak 1024 UKM. Penelitian ini merupakan penelitian kuantitatif dengan menggunakan data sekunder dari The World Bank Enterprise Survey 2009 dengan analisis uji regresi ordinal. Hasil penelitian ini menunjukkan bahwa verifikasi laporan keuangan berpengaruh pada akses pendanaan UKM. Dengan demikian, penelitian ini menyarankan bahwa verifikasi laporan keuanga penting bagi UKM, terutama dalam mengatasi masalah akses pendanaan yang sering

\section{PENDAHULUAN}

Usaha Kecil dan Menengah (UKM) memiliki peran penting bagi perekonomian Indonesia karena sebagai penggerak perekonomian bangsa dalam penyerapan tenaga kerja dan pertumbuhan. Sampai saat ini jumlah UKM di Indonesia sebanyak 58,91 juta unit jenis usaha mikro, 59.260 unit usaha kecil, dan sebanyak 4.987 unit jenis usaha besar menurut Deputi Bidang Pembiayaan Kementerian Koperasi dan UKM (Kemkop UKM). UKM sendiri adalah sarana menciptakan wirausaha baru yang mampu bertahan dalam lingkungan bisnis karena dorongan terus bertambahnya jumlah pengangguran setiap tahunnya. Kemudian hal tersebut perlu terus dikembangkan bahkan perlu adanya peningkatan pengelolaannya agar menjadi lebih baik lagi.

Demi kelancaran kegiatan operasional UKM tersebut mereka membutuhkan pendanaan, namun UKM menghadapi beberapa kendala. Pembiayaan usaha, masalah akumulasi modal, dan cara memanfaatkan fasilitas dalam kegiatannya adalah bebera- 
pa kendala dalam permodalan.

Salah satuh satu hal yang menjadi kendala yaitu kurangnya permodalan. Hal ini yang terjadi karena UKM merupakan usaha perorangan atau usaha yang bersifat tertutup, hanya mengandalkan modal pemilik dengan jumlah terbatas, sedangkan modal pinjaman dari bank atau lembaga keuangan lain sulit diperoleh karena persyaratan administratif dan teknis tidak dapat dipenuhi (Kristiyanti, 2012). Pemerintah menyediakan program pembiayaan bagi UKM yaitu Kredit Usaha Rakyat (KUR) yang disalurkan melalui lembaga keuangan perbankan. KUR bertujuan sebagai solusi pembiayaan bagi UKM, namun dalam penyaluran KUR bank yang ditunjuk pemerintah masih berhati-hati karena ti-dak memiliki akses informasi yang memadai ter-kait UKM (Susanto \& Yuliani, 2015). Banyak faktor yang menyebabkan sulitnya akses pendanaan pada UKM salah satunya adalah UKM belum tersentuh lembaga keuangan formal seperti bank. UKM ter-paksa hanya memanfaatkan jasa lembaga keuangan mikro tradisional yang memiliki beban dan risiko cukup berat demi mempertahankan kelangsungan usahanya. Menurut Warsadi, Herawati, \& Julianto (2017) pemikiran mengenai pengelolaan keuangan dan sumber daya yang terbatas dalam menyusun laporan keuangan, pemilik usaha belum mengelola usahanya dengan benar dan sesuai dengan standar yang berlaku. Kondisi tersebut harus membuat la-poran keuangan agar kondisi keuangan UKM dapat dilihat guna mengajukan kredit kepada bank.

Beberapa penelitian menunjukkan bahwa laporan keuangan yang berkualitas akan mempermudah akses pendanaan. Seperti dikatakan oleh Indrajaya, Herlina, \& Setiadi (2011) semakin terbuka akses terhadap sumber dana bagi perusahaan, selain menciptakan kemudahan juga menciptakan konse-kuensi dan dampak finansial yang berbeda. Dika-takan juga dalam penelitian Susanto \& Yuliani (2015) bahwa besarnya kredit yag diterima oleh UMKM tergantung pada kualitas laporan keuangannya, maka dari itu UMKM yang belum memiliki laporan keuangan perlu membuat laporan keuangan sebagai persyaratan pengajuan kredit. Tingginya tingkat pendidikan akan berpengaruh pada pemahaman mengenai pembukuan, maka semakin paham juga terhadap laporan keuangan. Pada penelitian Sandrayati, Masnila, \& Sari (2015) dika-takan juga bahwa laporan keuangan yang berkualitas juga dipengaruhi oleh tingkat pendidikan karyawan. Tingkat pendidikan dan pelatihan akuntansi akan memberikan pengaruh terhadap penerapan akuntansi pada UKM.
Pelayanan perbankan yang mudah diakses akan mempermudah banyak orang untuk melakukan aktifitas perbankan seperti meminjam kredit ataupun menabung, sehingga mereka dapat membangun aset dan juga membantu kegiatan usaha ataupun perdagangan (Steelyana, 2013). Usaha Kecil dan Menengah (UKM) harus bersaing untuk mendapatkan sumber pendanaan karena pihak lain yang berniat memberikan pinjaman akan melihat profitabilitas pada perusahaan tersebut. Menurut Ida (2010) pengelolaan dana mencakup bagaimana manager keuangan memperoleh sumber dana yang efisien dan mengalokasikan atau menginvestasikan secara efektif. Kemampuan UKM dalam menyusun laporan keuangan merupakan hal yang penting, sehingga UKM dapat mengerti dengan benar dan mampu menerapkan akuntansi dan laporan keuangan dengan baik. Sehingga laporan keuangan yang berkualitas merupakan salah satu hal yang penting. Dalam penelitian ini berfokus pada pentingnya melakukan verifikasi laporan keuangan, karena verifikasi laporan keuangan menunjukkan bahwa laporan keuangan tersebut berkualitas dan akan lebih menyakinkan pemberi sumber pendanaan.

Ketika laporan keuangan tersebut sudah diverifikasi, maka UKM (Usaha Kecil dan Menengah) akan lebih mudah untuk mendapatkan sumber pendanaan. Verifikasi laporan keuangan juga akan memberikan informasi tambahan kepada kreditor. Pihak manajemen akan berusaha mendapatkan lebih banyak sumber pendanaan pada peru-sahaan untuk mendanai kegiatan operasional yang mungkin tidak terpenuhi, jika hanya mengandalkan sumber dana internal dan pinjaman bank saja. Cara lain untuk memenuhi kebutuhan dana tersebut dapat dilakukan dengan menjual kepemilikan saham perusahaan kepada investor (Iskandar \& Trisnawati, 2010). Dewi \& Wirajaya (2013) mengatakan bahwa ukuran perusahan dianggap dapat mempengaruhi nilai perusahaan. Semakin besar ukuran atau skala perusahaan, maka akan semakin mudah pula peru-sahaan memperoleh sumber pendanaan yang bersifat internal maupun eksternal.

Berdasarkan latar belakang diatas, penelitian ini bertujuan untuk menganalisis peran verifikasi laporan keuangan dalam meningkatkan akses pendanaan pada UKM. Penelitian ini menarik untuk di-teliti karena masih sedikitnya UKM yang melakukan verifikasi laporan keuangan. Penelitian ini bertu-juan untuk mengetahui apakah verifikasi laporan keuangan mempengaruhi akses pendanaan pada UKM. 


\section{PENGEMBANGAN HIPOTESIS}

Akses pendanaan pada UKM merupakan fak-tor utama demi melancarkan kegiatan operasional mereka. Semakin baik akses pendanaan pada UKM, maka dana yang didapatkan juga akan semakin mu-dah. Akses ke layanan keuangan, terutama oleh UKM menjadi hal penting di banyak negara ber-kembang. UKM merupakan bagian besar dari sektor swasta yang muncul di sebagian besar negara, tetapi juga lebih dibatasi dalam akses mereka ke layanan keuangan daripada perusahaan besar. (Beck \& Demirguc-kunt, 2007). Hope, Thomas, \& Vyas (2011) mengatakan bahwa ketika laporan keuangan kredi-bel, maka akan meningkatkan akses pendanaan UKM, karena kredibilitas keuangan memiliki dampak yang lebih besar pada pengurangan kendala keuangan. Laporan keuangan merupakan hasil pro-ses akuntansi yang menyediakan informasi keuangan bagi pihak berkepentingan dalam pengambilan keputusan (Ningtyas, 2017). Bankir, kreditor, pemilik dan pihak-pihak yang berkenpentingan memerlukan laporan keuangan untuk menganalisa kinerja keuangan dan kondisi usaha. Laporan keuangan merupakan salah satu hal penting untuk UKM, karena akan mempermudah sumber pendanaan (Ikatan Akuntansi Indonesia, 2016). Laporan keuangan pada UKM ju-ga akan membantu untuk mengalokasikan sumber daya ekonomi secara efisien, membantu UKM untuk dapat memperoleh dana, mempertanggungjawabkan pengelolaan keuangan, serta memfasilitasi fungsi dan pengendalian sosial.

Sumber pendanaan yang diperoleh UKM dapat bersifat internal maupun eksternal, tergantung darimana mendapatkan dana tersebut. Sumber internal berasal dari modal pemilik. Sedangkan sumber eksternal dapat diperoleh dari supplier maupun kredit dari bank. Utang yang digunakan sebagai sumber pendanaan eksternal perusahaan akan menimbulkan biaya modal sebesar biaya bunga yang dibebankan kreditur. Jika manajer menggunakan dana internal atau sendiri, maka akan timbul opportunity cost dari dana atau modal sendiri yang digunakan (Firnanti, 2011). Selain pinjaman bank, kredit perdagangan juga merupakan sumber pembiayaan eksternal UKM yang paling penting di hampir setiap pembangunan dan ekonomi (CarbóValverde, Rodríguez-Fernández, \& Udell, 2016). Pengajuan kredit perbankan menjadi salah satu usaha untuk mendapatkan modal. Melalui Kredit Usaha Rakyat (KUR) pemerintah Indonesia mendukung mendukung terkait pembiayaan UKM.
Laporan keuangan yang berkualitas akan lebih mudah untuk dilakukan verifikasi. Dalam hal ini laporan keuangan yang berkualitas adalah laporan keuangan di dalamnya termasuk minimal tiga komponen laporan keuangan, yaitu laporan posisi keuangan (neraca), laporan perubahan modal dan laporan laba rugi (Trisnawati \& Situmorang, 2015). Susanto \& Yuliani (2015) mengatakan bahwa kua-litas laporan keuangan terkait dengan pentingnya pembukuan dan pelaporan keuangan UKM bagi usahanya yang dilakukan oleh pemilik. Sehingga menjadikan verifikasi laporan keuangan salah satu hal penting karena akan meningkatkan kepercayaan pada kreditur untuk memberikan pinjaman pada UKM. Hal ini perlu dilakukan UKM agar akses pendanaan lebih baik dan merupakan bentuk penga-wasan untuk memastikan apakah laporan keuangan sudah diverifikasi sesuai dengan standar yang berlaku. Kemudian auditor eksternal memberikan verifikasi independen bahwa informasi yang disediakan bebas dari salah saji yang material, sehingga meningkatkan kredibilitasnya. Kredibilitas tambahan dapat terjadi baik melalui proses verifikasi secara langsung untuk meningkatkan kualitas lapo-ran keuangan atau melalui perusahaan berkualitas tinggi yang dapat memberi sinyal jenis perusahaannya dengan me-nyajikan laporan keuangan yang telah diverifikasi (Hope et al., 2011).

Ketika laporan keuangan diverifikasi, maka akan menunjukkan keadaan keuangan UKM yang kemudian akan mengurangi hambatan keuangan. Salah satu penyebab adanya persyaratan laporan keuangan yang sesuai standar akuntansi keuangan yang berlaku di Indonesia ingin mendapatkan kredit pada lembaga keuangan tersebut (Cahyati, Mulyanti, \& Setyawasih, 2011). Saat laporan keuangan sudah diverifikasi akan meningkatkan tingkat suku bunga dan juga menurunkan risiko penolakan pinjaman. Masalah lain dari pilihan verifikasi sangat erat kaitannya, karena penghapusan verifikasi pada umumnya akan merusak reputasi perusahaan dan akan dianggap sebagai sinyal negatif, karena akan meminimalkan variasi laporan keuangan yang diverifikasi (Ding, Liu, \& Wu, 2016).

$\mathrm{H}_{1}$ : Verifikasi terhadap laporan keuangan pada UKM akan berpengaruh positif pada akses pendanaan.

\section{DATA DAN METODE}

\section{Jenis dan Sumber Data}

Penelitian ini merupakan penelitian kualitatif 
dengan menggunakan data sekunder yang diperoleh dari The World Bank Indonesia Enterprise Survey 2009. Obyek penelitian ini merupakan Usaha Kecil dan Mengah (UKM) dengan jumlah keseluruhan sampel awal yang digunakan sebanyak 1444. Dalam keseluruhan data sampel tersebut terdapat perusahaan perseorangan, CV, dan PT. Dari total UKM sebanyak 1.444 diperoleh hasil akhir untuk pene-litian ini sebanyak 1.024 karena penelitian ini telah menghilangkan kriteria untuk usaha yang tergolong usaha besar.

\section{Variabel Penelitian}

Verifikasi laporan keuangan merupakan variabel utama atau variabel independen dalam penelitian ini. Verifikasi bertujuan untuk mengindikasi apakah laporan keuangan pada UKM sudah diverifikasi oleh auditor eksternal atau belum. Hal ini dinyatakan dalam questionnaire, yaitu dalam lapor-an tahunan, apakah pendiri memiliki laporan keuangan tahunan yang sudah dicek dan dijamin oleh auditor internal? (In fiscal year, did this establishment have its annual financial statements checked and certifies by an external auditor?). Pertanyaan tersebut menghasilkan data, yaitu angka 1 menjawab pertanyaan "ya" sedangkan angka 0 menjawab pertanyaan "tidak".

Variabel dependen yang diuji dalam penelitian ini adalah akses pendanaan. Berdasarkan survei dinyatakan bahwa dalam menggunaakan pilihan jawaban pada kartu; apakah menunjukkan berapa tingkat pada akses pembiayaan menjadi kendala untuk operasi pada saat didirikan? (Using the res-ponse options on the card; To what degree is Access to Finance an obstacle to the current operation of this establishment?). Dapat dijelaskan bahwa proksi utama dalam akses pendanaan adalah pada skala 4 (tidak ada masalah pada akses pendanaan) sampai 0 (hambatan keuangannya tinggi)

Adapun variabel lain dalam penelitian ini yaitu umur UKM dan jumlah tenaga kerja yang disebut variabel kontrol. Umur dapat mempengaruhi akses pendanaan pada UKM, karena kreditur akan melihat rekam jejak sebelum memberikan pinjaman. Semakin lama UKM tersebut berdiri maka akan semakin banyak pula rekam jejak pada UKM tersebut. Biasanya UKM yang sudah lama berdiri akan membuat kreditor lebih mudah memberikan pinjaman. Tetapi tidak semua UKM yang sudah berdiri lama memiliki rekam jejak yang baik. Pengukuran umur dilakukan dengan cara mengurangkan tahun survei yaitu tahun 2009 dengan tahun berdiri UKM tersebut.

Ukuran UKM menjadi salah satu yang dapat mempengaruhi akses pendanaan, dalam penelitian ini ukuran UKM dilihat dari jumlah tenaga kerja. Tenaga kerja pada UKM ini yaitu tenaga kerja tetap, yang merupakan pekerja bayaran waktu penuh yang dikontrak untuk satu periode atau lebih.

Tabel 1. Operasionalisasi Variabel Penelitian

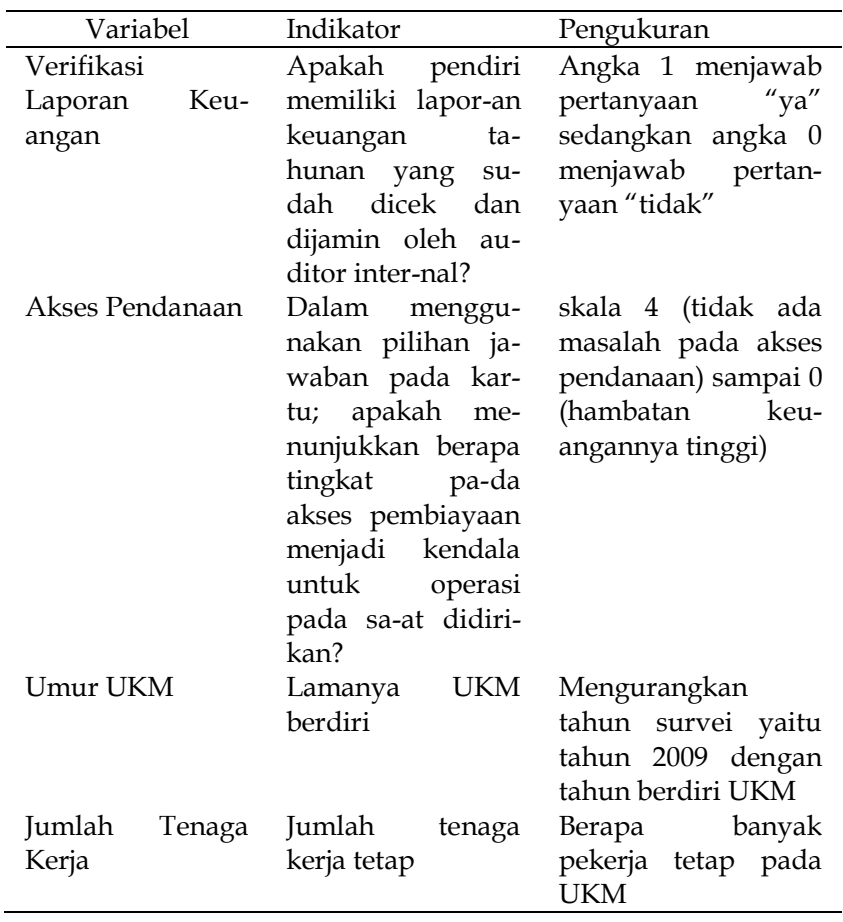

\section{Pengukuran}

Untuk menguji sampel, teknik analisis yang digunakan dalam penelitian ini yaitu uji regresi ordinal. Dimana akses pendanaan sebagai variabel de-penden dan verifikasi laporan keuangan menjadi variabel independen. Variabel kontrol yang ada terdiri dari umur UKM dan jumlah tenaga kerja. Persamaan regresi dapat dijelaskan sebagai berikut:

$$
Y=\alpha+\beta_{\text {verifikasi }}+\beta_{\text {umurUKM }}+\beta_{\text {jumlahTKL }}+\varepsilon_{\ldots}
$$

Keterangan: $Y=$ Akses pendanaan; $\alpha=$ konstanta; $\beta_{\text {verifikasi }}=$ verifikasi laporan keuangan; $\beta_{\text {umurUKM }}=$ umur UKM; $\beta_{\text {jumlah TKL }}=$ jumlah tenaga kerja; dan $\varepsilon=$ error. Dimana Laporan keuangan, umur UKM dan jumlah tenaga kerja merupakan variabel kontrol.

\section{HASIL}

Jumlah sampel awal yang digunakan sebanyak 1.444 usaha terdiri dari usaha besar, usaha menengah dan usaha kecil. Sedangkan dalam penelitian ini hanya menggunakan usaha kecil dan menengah yang tergolong sebagai UKM sesuai dengan kriteria pada The World Bank Indonesia En- 
terprise Survey 2009. Jumlah tenaga kerja sebagai kriteria penggolongan usaha; yaitu 5-19 tenaga kerja merupakan usaha kecil, kemudian 20-99 tenaga ker-ja merupakan usaha menangah, sedangkan tenaga kerja diatas 100 orang merupakan usaha besar. Sehingga tenaga kerja yang berjumlah 100 orang langsung dihapuskan karena tidak memenuhi kriteria dari penelitian. Setelah dilakukan penghapusan sampel diperoleh sampel akhir sebanyak 1024 yang dapat dilihat pada tabel 2 .

Tabel 2. Jenis Usaha

\begin{tabular}{llc}
\hline No & Jenis Usaha & Jumlah Sampel \\
\hline 1. & Usaha Kecil & 715 \\
2. & Usaha Menengah & 309 \\
Total Sampel Akhir & 1024 \\
\hline
\end{tabular}

Secara umum dilihat dari tabel 3 UKM yang telah melakukan verifikasi laporan keuangan berjumlah 76 UKM (5,3\%). Sedangkan 948 (65,7\%) lainnya belum melakukan verifikasi laporan keuangan. Hal ini menunjukkan bahwa UKM banyak yang belum melakukan verifikasi laporan keuangan. Kondisi ini dapat terjadi karena karakteristik UKM yang laporan keuangannya masih sangat terbatas.

Tabel 3. Persepsi Verifikasi Laporan Keuangan

\begin{tabular}{lrl}
\hline Persepsi & Frekuensi & $(\%)$ \\
\hline Tidak Melakukan Verifikasi & 948 & 65,7 \\
Melakukan Verifikasi & 76 & 5,3 \\
Total & 1024 & 100 \\
\hline Missing system & 420 & 29,1 \\
\hline
\end{tabular}

Berdasarkan tabel 4 sejumlah 384 UKM $(26,6 \%)$ tidak mengalami kesulitan akses pendanaan atau akses pendanaannya terbilang baik. Berdasarkan data-data tersebut menunjukkan bahwa secara umum UKM tidak mengalami kesulitan dalam mengakses pendanan. Sedangkan UKM yang mengalami kesulitan atau dalam mengkases pendanaan hanya sedikit. Hal ini menunjukkan bahwa secara keseluruhan, rata-rata UKM dalam mengakses sumber pendanaan relatif mudah. Kemudahan dalam mengakses sumber pendanaan ini menjadi penting dalam pengembangan usahanya. UKM dalam me-ngakses sumber pendanaan dari lembaga keuangan relative tidak ada hambatan.

Tabel 4. Persepsi Akses Pendanaan

\begin{tabular}{lcc}
\hline Persepsi & Frekuensi & Prosentase (\%) \\
\hline Very severe obstacle & 31 & 2,1 \\
Major obstacle & 113 & 7,8 \\
Moderate obstacle & 251 & 17,4 \\
Minor obstacle & 245 & 17 \\
No obstacle & 384 & 26,6 \\
Total & 1024 & 100 \\
\hline Missing system & 420 & 29,1 \\
\hline
\end{tabular}

Tabel 5 menunjukkan bahwa sebagian besar UKM yang berada di Indonesia yaitu sejumlah 793 $(54,9 \%)$ merupakan jenis usaha yang bergerak di bidang manufaktur. Sebagai mana karakteristik perusahaan yang bergerak di bidang manufaktur, maka kebutuhan dana relative besar. Dimana sumber dana tersebut dapat ditopang dari hutang. Sehingga akses pendanaan menjadi factor penting.

Tabel 5. Persepsi Jenis UKM

\begin{tabular}{lcc}
\hline \multicolumn{1}{c}{ Persepsi } & Frekuensi & Prosentase (\%) \\
\hline Manufacturing & 793 & 54,9 \\
Retail services & 109 & 7,5 \\
Other services & 122 & 8,4 \\
Total & 1024 & 100 \\
\hline Missing system & 420 & 29,1 \\
\hline
\end{tabular}

Berdasarkan tabel 6 sebagian besar UKM merupakan usaha kecil dengan karyawan berjumlah 5-19 saja. Dapat dilihat bahwa usaha kecil berjumlah $715(49,5)$ unit, sedangkan usaha menenagh berjumlah $309(21,4)$ unit.

Tabel 6. Persepsi Ukuran UKM

\begin{tabular}{lcc}
\hline \multicolumn{1}{c}{ Persepsi } & Frekuensi & Prosentase $(\%)$ \\
\hline Small & 715 & 49,5 \\
Medium & 309 & 21,4 \\
Total & 1024 & 100 \\
\hline Missing system & 420 & 29,1 \\
\hline
\end{tabular}

Usia UKM relatif bervariasi, yaitu antara 2-88 tahun (tabel 7). Rata-rata usia UKM 6,01 tahun, hal ini menunjukkan bahwa hanya sebagian kecil UKM yang telah berusia lama, namun sebagian besar masih realtif muda.

Tabel 7. Statistika Deskriptif Umur Usaha

\begin{tabular}{llrcl}
\hline & $\mathrm{N}$ & Minimum & Maksimum & Rata-rata \\
\hline $\begin{array}{l}\text { Umur } \\
\text { usaha }\end{array}$ & 1024 & 2 & 88 & 6,01 \\
\hline
\end{tabular}

\section{Korelasi Variabel Independen}

Berdasrkan tabel 8 yang menunjukkan hasil tes dari korelasi antara verifikasi, jenis UKM, ukuran UKM, dan umur usaha sebagai variabel indepen-den. Hasil dari tes ini menunjukkan bahwa nilai korelasinya rendah dan multikoleniaritas tidak terde-teksi antara variabel independen dilihat dari nilai koefisien korelasi dibawah 0,5. Berdasarkan korelasi menunjukkan bahwa akses pendanaan berkorelasi positif dengan ukuran UKM, artinya semakin UKM besar, maka aksesnya akan semakin meningkat. Ve-rifikasi laporan keuangan berkorelasi positif dengan akses pendanaan, jenis UKM, ukuran UKM dan juga umur UKM. 
Tabel 8. Tes Pearson

\begin{tabular}{lccccc}
\hline & $\begin{array}{c}\text { Akses } \\
\text { Pendanaan }\end{array}$ & Verifikasi & Jenis UKM & Ukuran UKM & Umur Usaha \\
\hline Akses Pendanaan & 1,000 & 0,048 & 0,195 & 0,043 & $-0,037$ \\
Verifikasi Laporan Keuangan & 0,048 & 1,000 & 0,163 & 0,171 & 0,038 \\
Jenis UKM & 0,195 & 0,163 & 1,000 & $-0,127$ & $-0,131$ \\
Ukuran UKM & 0,043 & 0,171 & $-0,127$ & 1,000 & 0,204 \\
Umur Usaha & $-0,037$ & 0,038 & $-0,131$ & 0,204 & 1,000 \\
\hline
\end{tabular}

\section{Analisis Regresi Ordinal}

Penelitian ini menggunakan STATA untuk menguji data dan menjalankan analisis regresi ordinal dengan standart error yang kuat. Pada tabel 9 menunjukkan bahwa verifikasi laporan keuangan mempengaruhi akses pendanaan pada UKM. Verifikasi berpengaruh positif pada akses pendanaan dengan nilai signifikansi $(0,004, \mathrm{z}=2,86)$ yang menunjukkan laporan keuangan UKM yang diverifikasi akses pendanaannya akan semakin mudah.
Kemudian untuk variabel kontrol jenis UKM dan ukuran UKM juga berpengaruh positif terhadap akses pendanaan. Jenis UKM memiliki nilai signifikansi $(0,000, \mathrm{z}=692)$ yang mendeskripsikan apakah UKM termasuk manufaktur, retail, dan jasa lain. Kemudian nilai signifikansi ukuran UKM $(0,000, z=5,48)$ menunjukkan apakah UKM tersebut dikategorikan sebagai usaha menengah atau kecil dilihat dari jumlah tenaga kerja.

Tabel 9. Uji Regresi Ordinal

\begin{tabular}{lllll}
\hline Akses Pendanaan & Coef. & Robust Std. Err. & $\mathrm{z}$ & $\mathrm{P}>\mathrm{I}$ z I \\
\hline Verifikasi Laporan Keuangan & 0,2137018 & 0,745907 & 2,86 & 0,004 \\
Jenis UKM & 0,6108818 & 0,0883409 & 6,92 & 0,000 \\
Ukuran UKM & 0,3615255 & 0,0660151 & 5,48 & 0,000 \\
Umur Usaha & 0,0001441 & 0,0042477 & 0,03 & 0,973 \\
\hline
\end{tabular}

Secara keseluruhan dapat diketahui bahwa verifikasi laporan keuangan meningkatkan akses pendanaan pada UKM. Temuan ini mendukung hipotesis yang telah dibuat yaitu bahwa verifikasi terhadap laporan keuangan akan berpengaruh posi-tif terhadap akses pendanaan. Tetapi juga dapat diketahui bahwa lamanya usaha tersebut berdiri tidak berpengaruh untuk akses pendanaan yang lebih baik, karena secara empiris umur usaha tidak signifikan.

\section{PEMBAHASAN}

Hasil dari penelitian ini menunjukkan bahwa ketika suatu UKM melakukan verifikasi pada laporan keuangannya, maka akses pendanaan pada UKM tersebut akan semakin mudah. Hal ini terjadi karena laporan keuangan yang diverifikasi akan menimbulkan kepercayaan kepada sumber peminjam. Akses pendanaan, syarat dan ketentuan UKM untuk meminjam dari lembaga keuangan dapat ditentukan dari kekayaan bersih pemilik, jaminan, rencana bisnis, arus kas, serta laporan keuangan (Harvie, Narjoko, \& Oum, 2013). Akses pendanaan yang baik juga diperoleh dari kenyakinan UKM bahwa keterampilan manajemen informasi penting
(Tagoe, Amarh, \& Nyarko, 2008).

Verifikasi laporan keuangan berfungsi untuk mengetahui apakah laporan keuangan pada UKM sudah tersusun se-suai dengan standar yang berlaku umum. Sehingga ketika laporan keuangan pada UKM telah diverifikasi akses pendaannya akan semakin mudah, karena pemilik modal akan lebih percaya. Kegiatan memverifikasi laporan keuangan tersebut dilaku-kan oleh auditor eksternal yang bertanggungjawab untuk memberikan opini terkait dengan laporan keuangan UKM.

Verifikasi laporan keuangan menjadi suatu hal yang perlu dilakukan agar aksesnya dalam pendanaan semakin mudah. Ketika akses pendanaan pada UKM semakin mudah, kegiatan operasional pada UKM tersebut akan berjalan lancar. Kebutuhan dana UKM akan dengan mudah terpenuhi. Namun demikian, tidak sedikit juga UKM yang tidak memverikasi laporan keuangan mereka. Hal tersebut terjadi karena pengusaha UKM ataupun orang yang bertanggungjawab terhadap laporan keuangan kurang memahami akuntansi. Minimnya pendidikan yang diemban juga menjadi salah satu faktor kualitas laporan keuangan pada UKM belum cukup baik. Ketika laporan keuangan pada UKM tidak diverifikasi, maka akses penda- 
naannya akan tersendat, karena laporan keuangan yang duverifikasi menjadi salah satu jaminan dalam meminjam dana. Sehingga dapat diartikan bahwa pemahaman akuntansi yang baik akan meningkatkan kualitas laporan keuangan. Namun dapat diketahui juga bahwa UKM yang tidak melakukan verifikasi laporan keuangan juga memiliki akses pendanaan yang baik. Hal tersebut terjadi karena dana yang digunakan untuk kegiatan operasionalnya merupakan dana pribadi dan tidak meminjam dari lembaga keuangan. Secara keseluruhan dari penelitian ini menunjukkan bahwa UKM yang memverifikasi laporan keuangannya, akses pendanaan UKM juga akan semakin baik. Dikatakan dalam penelitian Indrajaya, Herlina, \& Setiadi (2011) bahwa suatu perusahaan yang akses pendanaannya semakin terbuka, maka akan menciptakan kemudahan dalam memperoleh pinjaman.

\section{SIMPULAN DAN SARAN}

Penelitian ini menunjukkan bahwa verifikasi laporan keuangan berpengaruh pada akses pendanaan. Diketahui juga bahwa akses pendanaan yang didapat UKM relatif mudah meskipun mereka tidak melakukan verifikasi laporan keuangan. Kemudian untuk variabel kontrol lain seperti jenis UKM dan ukuran UKM menunjukkan nilai signifikan yang berarti memberikan pengaruh terhadap akses pendanaan.

Penelitian ini memiliki beberapa keterbatasan. Pertama, survei menggunakan skala yang berbeda untuk masing-masing variabel baik dependen maupun independen, yaitu data ordinal dan nominal. Kedua, masih adanya beberapa variabel yang mungkin mempengaruhi akses pendanaan tetapi tidak digunakan dalam penelitian ini. Untuk pe-nelitian selanjutnya, diharapkan peneliti dapat me-nyamakan skala yang digunakan karena menggunakan skala yang berbeda akan memberikan kelemahan terhadap hasil yang diperoleh. Kemudian dapat mempertimbangkan untuk menambah variabel lain: penjualan, pengalaman, keterampilan yang dapat mempengaruhi akses pendanaan.

\section{DAFTAR PUSTAKA}

Beck, T., \& Demirguc-kunt, A. (2007). Small and Medium Enterprises Across the Globe. Small Business Economics,: 415-416.

Cahyati, A. D., Mulyanti, K., \& Setyawasih, R. (2011). Pemahaman Dan Kesiapan Ukm Dalam Implementasi Sak Etap: Survey Pada UKM Di Bekasi. Jurnal Riset Akuntansi $\mathcal{E}$ Komputerisasi Akuntansi, Vol. 2(2): 19-27.
Carbó-Valverde, S., Rodríguez-Fernández, F., \& Udell, G. F. (2016). Trade Credit, the Financial Crisis, and SME Access to Finance. Journal of Money, Credit and Banking, Vol. 48(1): 113-143.

Dewi, A. S. M., \& Wirajaya, A. (2013). Pengaruh Struktur Modal, Profitabilitas dan Ukuran Perusahaan Pada Nilai Perusahaan. E-Journal Akuntansi Universitas Udayana, Vol. 4(2): 358372.

Ding, S., Liu, M., \& Wu, Z. (2016). Financial Reporting Quality and External Debt Financing Constraints: The Case of Privately Held Firms. Abacus, Vol. 52(3): 351-373.

Firnanti, F. (2011). Faktor Faktor yang Mempengaruhi Struktur Modal Perusahaan Manufaktur di Bursa Efek Indonesia. Jurnal Bisnis Dan Akuntansi, Vol.13(2): 119-128.

Harvie, C., Narjoko, D., \& Oum, S. (2013). Small and Medium Enterprises' Access to Finance: Evidence from Selected Asian Economies. ERIA Discussion Paper Series.

Hope, O. K., Thomas, W., \& Vyas, D. (2011). Financial credibility, ownership, and financing constraints in private firms. Journal of International Business Studies, Vol. 42(7): 935-957.

IAI. (2016). Standar Akuntansi Keuangan Entitas Mikro, Kecil, dan Menengah.

Ida. (2010). Pemilihan Sumber Pendanaan Perusahaan Berdasarkan Hipotesis Pecking Order Ida. Jurnal Akuntansi, Vol. 2(1): 93-100.

Indrajaya, G., Herlina, \& Setiadi, R. (2011). Pengaruh Struktur Aktiva, Ukuran Perusahaan, Tingkat Pertumbuhan, Profitabilitas, dan Risiko Bisnis Terhadap Struktur Modal: Studi Empiris Pada Perusahaan Sektor Pertambangan yang Listing di Bursa Efek Indonesia Periode 2004-2007. Jurnal Ilmiah Akuntansi, Vol (6): 1-23.

Iskandar, M. J., \& Trisnawati, E. (2010). FaktorFaktor yang Mempengaruhi Audit Report Lag pada Perusahaan yang Terdaftar di Bursa Efek Indonesia. Jurnal Bisnis Dan Akuntansi, 12(3): 175-186.

Kristiyanti, M. (2012). Peran Strategis Usaha Kecil Menengah ( UKM ) Dalam Pembangunan Nasional. Majalah Ilmiah Informatika, Vol. 3(1).

Ningtyas, J. D. A. (2017). Penyusunan Laporan Keuangan UMKM Berdasarkan Standar Akuntansi Keuangan Entitas Mikro, Kecil dan Menengah ( SAK-EMKM ) ( Study Kasus Di UMKM Bintang Malam Pekalongan ). Riset E Jurnal Akuntansi, Vol. 2(1).

Sandrayati, Masnila, N., \& Sari, Y. (2015). 
Pendidikan dan Pelatihan Dalam Kaitannya Dengan Pemahaman dan Penerapan Akuntansi Pada UKM. Prosiding SNaPP2016 Sosial, Ekonomi, Dan Humaniora,: 800-805.

Steelyana, E. (2013). Perempuan dan Perbankan: Sebuah Tinjauan Tentang Peran Inklusi Keuangan Terhadap Pengusaha UMKM Perempuan di Indonesia. Journal The Winners, Vol. 14(2): 95-103.

Susanto, B., \& Yuliani, N. L. (2015). Prospek Implementasi SAK ETAP Berbasis Kualitas Kaporan Keuangan UMKM. Jurnal Ekonomi Dan Bisnis Optimum, : 1-17.

Tagoe, N., Amarh, E. A., \& Nyarko, E. (2008). SME Access To Bank Finance In An Emerging Economy: The Role Of Information Management Practices. Journal Financial Services Management, Vol. 3(2): 148-170.
Trisnawati, F., \& Situmorang, J. C. P. (2015). Kualitas Laporan Keuangan UKM Di Kota Pekanbaru. Jurnal Al-Iqtishad Edisi 11(1).

Warsadi, K. A., Herawati, N. T., \& Julianto, I. P. (2017). Penerapan Penyusunan Laporan Keuangan Pada Usaha Kecil Menengah Berbasis Standar Akuntansu Keuangan Entitas Mikro, Kecil, dan Menengah Pada PT. Mama Jaya. EJournal S1 Ak Universitas Pendidikan Ganesha, Vol. 8(2). 